\title{
Does a learned journal require regular re-vamping?
}

\author{
A. van Belkum ${ }^{1}$
}

Published online: 11 July 2016

(C) Springer-Verlag Berlin Heidelberg 2016

\section{Publishing in the clinical microbiology and infectious diseases' arena}

Many journals exist in our field and they all have their different merits, levels of visibility, and scientific reputation. Although the impact factor (IF) is an important parameter, it is certainly not the only quality determinant of a journal. For instance, the composition of the editorial board reflects the interest of key opinion leaders in a certain research field as promoted by a journal, and this helps to clinically and scientifically position such a journal. We have recently revamped the Advisory Board for the European Journal of Clinical Microbiology \& Infectious Diseases. Not because of dissatisfaction with the activities of previous Board members, but simply because being an Advisory Board member involves "activities" and we all have very busy agendas. So we would really like to thank, in alphabetical order, Matthew Falagas, Tim Harrison, Andy Hoepelman, Thierry Naas, Mike Pfaller, Marc Struelens, Ken Waites, Andreas Widmer, and Victor Yu for their past and, hopefully continued, support, albeit that the latter will be in a less formal fashion. We welcome new Board members. Nathan Wildeboer, Jordi Rello, Camilla Rodrigues, and François Vandenesch have kindly accepted to become actively involved in

A. van Belkum

alex.vanbelkum@biomerieux.com

bioMérieux, Scientific Office, 3, route de Port Michaud, 38390 La Balme-les-Grottes, France the management of the journal. When inviting the new Board members, we asked them to facilitate the following:

1. To allow us to "use" their good name and standing in the field of clinical microbiology and infectious diseases to draw attention to the journal and to try and attract good papers in their respective fields of expertise.

2. To ask them to think about possible improvements for the journal, whatever way it comes.

3. If compatible with their busy agendas, to submit (mini) reviews or editorials on topics of their personal interest.

4. To permit us to pick their brains for the possible development of special issues.

5. To ask them to keep the European Journal of Clinical Microbiology \& Infectious Diseases in mind if they themselves or their close colleagues submit papers for publication.

So, in short: we would like our Advisory Board members to be real ambassadors for the journal! Of course, we will try to organize board meetings, for instance during scientific conferences. However, the past has learned us that communication via e-mail is often more time-efficient. Dr. Willem van Leeuwen will stay on as Mini-review Editor for the years to come and feel free to address him should you have suggestions for topics or if you would have papers immediately available. Over the past years, Willem has managed to attract quite some mini-reviews that were essentially updates of major reviews written by the authors in spe three to four years ago. This gives the authors an opportunity 
Table 1 Most frequently downloaded papers published in the European Journal of Clinical Microbiology \& Infectious Diseases as monitored between 2011 and 2015

\begin{tabular}{lll}
\hline Reference & DOI & Number of Downloads \\
\hline Gable et al. 2009 [1] & $10.1007 / \mathrm{S} 10096-009-0799-0$ & 4448 \\
Krzyściak et al. 2014 [2] & $10.1007 / \mathrm{S} 10096-013-1993-7$ & 3458 \\
Reynolds 1989 [3] & $10.1007 / \mathrm{BF} 01967563$ & 2203 \\
Dunne et al. 2012 [4] & $10.1007 / \mathrm{S} 10096-012-1641-7$ & 2132 \\
Kohno et al. 2013 [5] & $10.1007 / \mathrm{S} 10096-012-1754-\mathrm{Z}$ & 2132 \\
Nicodemo and Garcia Paez 2007 [6] & $10.1007 / \mathrm{S} 10096-007-0279-3$ & 2077 \\
Döring et al. 2014 [7] & $10.1007 / \mathrm{S} 10096-013-1998-2$ & 1943 \\
Gullo et al. 2013 [8] & $10.1007 / \mathrm{S} 10096-013-1915-8$ & 1932 \\
Torres et al. 2014 [9] & $10.1007 / \mathrm{S} 10096-014-2067-1$ & 1804 \\
Gaspar et al. 2013 [10] & $10.1007 / \mathrm{S} 10096-013-1876-\mathrm{Y}$ & 1759 \\
Cunha 2012 [11] & $10.1007 / \mathrm{S} 10096-012-1680-0$ & 1751 \\
Kothavade et al. 2013 [12] & $10.1007 / \mathrm{S} 10096-012-1766-8$ & 1724 \\
\hline
\end{tabular}

to succinctly summarize the most recent developments in their field and, for us, it generates good papers that are usually extremely timely. Another "easy" category of mini-reviews to be exploited are the literature summaries that are a standard part of the $\mathrm{PhD}$ theses of young investigators. Again, these papers are complete and timely, and publishing such chapters generates additional and free visibility for young authors and their scientific mentors.

\section{A new category of papers?}

Scientific and also clinical research as published in scholarly journals is quite often externally funded and major clinical and scientific consortia are constantly developed in order for scientists to be more competitive and visible. Many such consortia get funded and, in general, the proposed work is executed successfully. Given the complexity and size of such consortia, the overall coherence of the work performed is not always clearly visible. We have given this considerable thought and we now offer authors the opportunity to review the outcomes and productivity of such collaborative efforts. In a forthcoming issue, you will see the first example of such a "Project Review" paper. Koulenti and colleagues review the overall achievements of the EU-CAP/VAP project (Koulenti D, Tsigou E, Rello J. Nosocomial pneumonia in 27 ICUs in Europe: perspectives from the EU-VAP/CAP study. Eur J Clin Microbiol Infect Dis. 2016 Jun 10. [Epub ahead of print] Review). We will start soliciting for additional Project Review papers as you read! Summarizing achievements through a Project Review paper enhances the yield of a project, improves its visibility, and, one never knows, may, in the end, contribute to the acquisition of new grants.
Table 2 Most cited papers published in the European Journal of Clinical Microbiology \& Infectious Diseases over the past 5 years

\begin{tabular}{lll}
\hline Reference & DOI & Total citations \\
\hline Guiso et al. 2011 [13] & $10.1007 / \mathrm{s} 10096-010-1104-\mathrm{y}$ & 64 \\
Ahmad et al. 2011 [14] & $10.1007 / \mathrm{s} 10096-010-1050-8$ & 59 \\
van Hal et al. 2011 [15] & $10.1007 / \mathrm{s} 10096-010-1128-3$ & 56 \\
Montassier et al. 2013 [16] & $10.1007 / \mathrm{s} 10096-013-1819-7$ & 48 \\
Dancer 2011 [17] & $10.1007 / \mathrm{s} 10096-011-1250-\mathrm{x}$ & 47 \\
Dubourg et al. 2013 [18] & $10.1007 / \mathrm{s} 10096-012-1787-3$ & 43 \\
Antinori et al. 2012 [19] & $10.1007 / \mathrm{s} 10096-011-1276-0$ & 42 \\
Dunne et al. 2012 [4] & $10.1007 / \mathrm{s} 10096-012-1641-7$ & 41 \\
Lambiase et al. 2011 [20] & $10.1007 / \mathrm{s} 10096-011-1182-5$ & 40 \\
Wang et al. 2012 [21] & $10.1007 / \mathrm{s} 10096-011-1328-5$ & 39 \\
\hline
\end{tabular}


Fig. 1 Annual increases in the yearly number of manuscripts submitted to the European Journal of Clinical Microbiology \& Infectious Diseases. Note that, now in the middle of 2016, we are up to more than 600 submissions

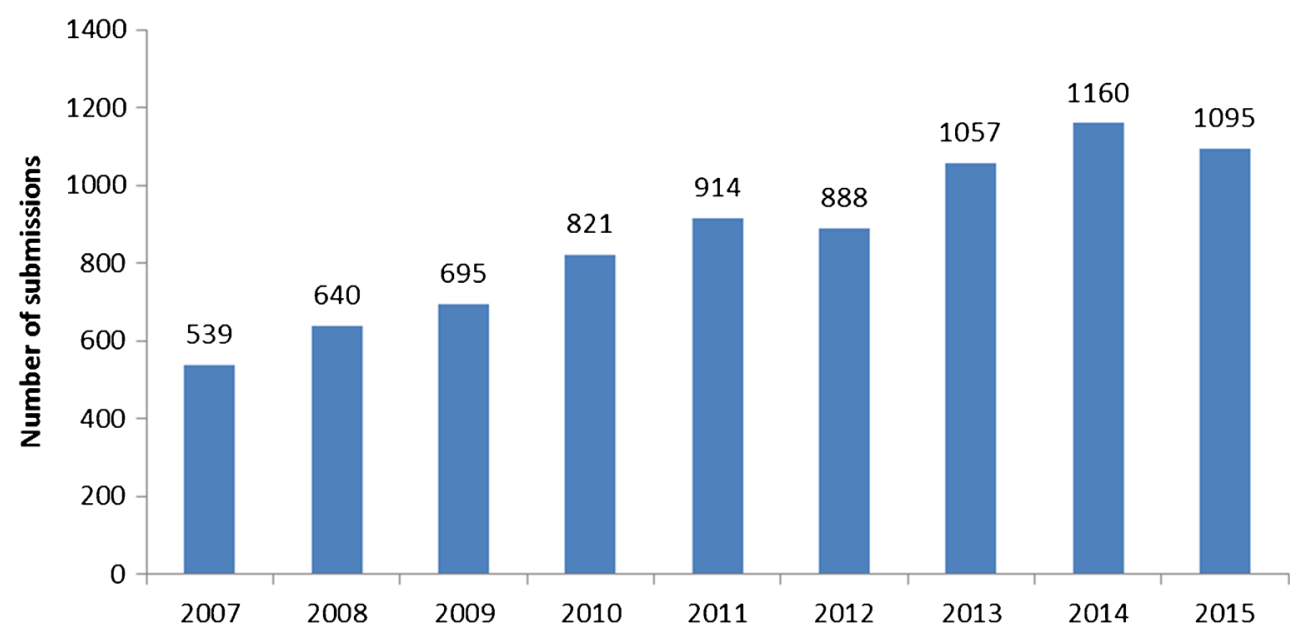

\section{To re-vamp or not?}

Journals offer services to a variety of audiences and ours is one of researchers in the field of laboratory science and clinical infectious diseases studies. We do tend not to focus too much on the impact factor of the journal (although our IF did rise from 2.668 for 2014 to 2.857 for 2015) but, rather, provide a forum for publishing practically valuable and clinically actionable research for actors in the field of clinical microbiology and infectious diseases. We are constantly trying to improve quality and attract the best work in this field. This, as you understand, is highly competitive and, for that, we need the support of our Advisory Board and, of course, the support of you, our readers. However, the journal as it is to date has successfully survived for decades and is in good shape. For that, we will, of course, continue evolving the journal, but we will do so at a leisurely pace at most.

\section{Thank you}

We thank you, our readers and authors, for your continued support. The European Journal of Clinical Microbiology \& Infectious Diseases is a healthy journal which is still wellcirculated in paper format, a feature that many of our readers still seem to enjoy in this increasingly electronic era. Feel free to reach out to me and Willem with specific requests, especially if you would be interested in writing a Project Review manuscript. Tables 1 and 2 as well as Figs. 1 and 2 as included in this editorial give you a small glimpse as to the development of the journal over the past period and, to me, this all looks positive. Looking forward to seeing your best work
Fig. 2 Overall number of downloads of papers published in the European Journal of Clinical Microbiology \& Infectious Diseases over the past 4 years. Note that, in 2013, we facilitated free downloading for a series of well-cited papers

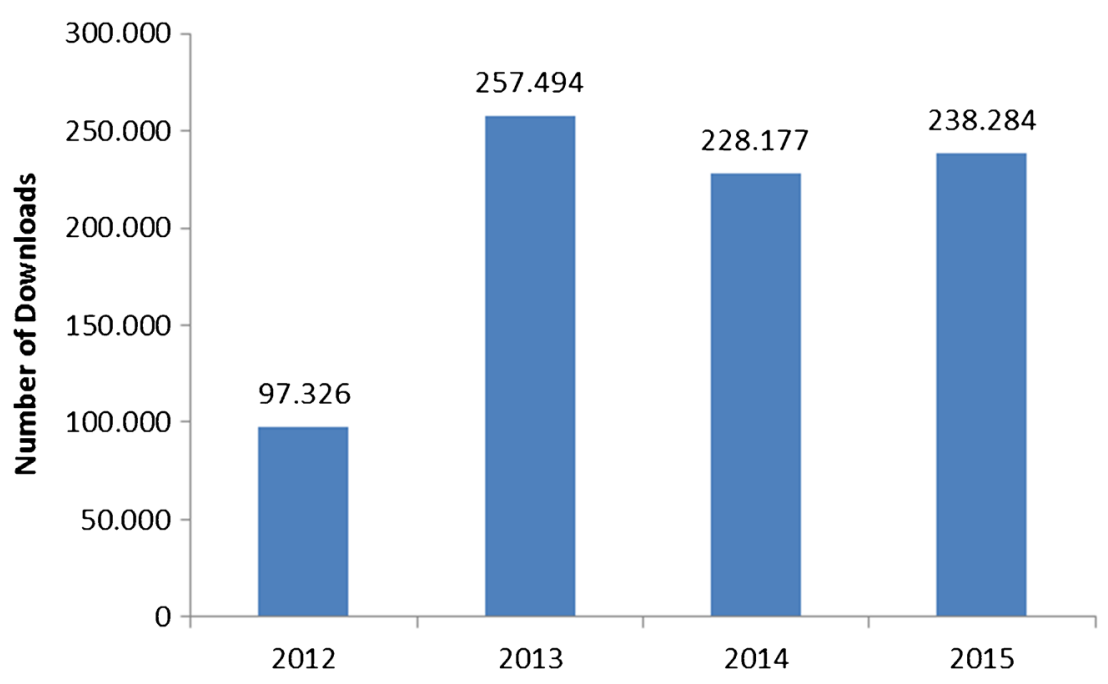


published in the European Journal of Clinical Microbiology \& Infectious Diseases!

\section{References}

1. Gable MS, Gavali S, Radner A, Tilley DH, Lee B, Dyner L, Collins A, Dengel A, Dalmau J, Glaser CA (2009) Anti-NMDA receptor encephalitis: report of ten cases and comparison with viral encephalitis. Eur J Clin Microbiol Infect Dis 28:1421-1429

2. Krzyściak W, Jurczak A, Kościelniak D, Bystrowska B, Skalniak A (2014) The virulence of Streptococcus mutans and the ability to form biofilms. Eur J Clin Microbiol Infect Dis 33:499-515

3. Reynolds PE (1989) Structure, biochemistry and mechanism of action of glycopeptide antibiotics. Eur J Clin Microbiol Infect Dis 8:943-950

4. Dunne WM Jr, Westblade LF, Ford B (2012) Next-generation and whole-genome sequencing in the diagnostic clinical microbiology laboratory. Eur J Clin Microbiol Infect Dis 31:1719-1726

5. Kohno S, Izumikawa K, Yoshida M, Takesue Y, Oka S, Kamei K, Miyazaki Y, Yoshinari T, Kartsonis NA, Niki Y (2013) A doubleblind comparative study of the safety and efficacy of caspofungin versus micafungin in the treatment of candidiasis and aspergillosis. Eur J Clin Microbiol Infect Dis 32:387-397

6. Nicodemo AC, Garcia Paez JI (2007) Antimicrobial therapy for Stenotrophomonas maltophilia infections. Eur J Clin Microbiol Infect Dis 26:229-237

7. Döring M, Blume O, Haufe S, Hartmann U, Kimmig A, Schwarze C-P, Lang P, Handgretinger R, Müller I (2014) Comparison of itraconazole, voriconazole, and posaconazole as oral antifungal prophylaxis in pediatric patients following allogeneic hematopoietic stem cell transplantation. Eur J Clin Microbiol Infect Dis 33:629638

8. Gullo FP, Rossi SA, Sardi JCO, Teodoro VLI, Mendes-Giannini MJS, Fusco-Almeida AM (2013) Cryptococcosis: epidemiology, fungal resistance, and new alternatives for treatment. Eur J Clin Microbiol Infect Dis 32:1377-1391

9. Torres A, Blasi F, Peetermans WE, Viegi G, Welte T (2014) The aetiology and antibiotic management of community-acquired pneumonia in adults in Europe: a literature review. Eur J Clin Microbiol Infect Dis 33:1065-1079
10. Gaspar MC, Couet W, Olivier J-C, Pais AACC, Sousa JJS (2013) Pseudomonas aeruginosa infection in cystic fibrosis lung disease and new perspectives of treatment: a review. Eur J Clin Microbiol Infect Dis 32:1231-1252

11. Cunha BA (2012) Oral doxycycline for non-systemic urinary tract infections (UTIs) due to P. aeruginosa and other Gram negative uropathogens. Eur J Clin Microbiol Infect Dis 31:2865-2868

12. Kothavade RJ, Dhurat RS, Mishra SN, Kothavade UR (2013) Clinical and laboratory aspects of the diagnosis and management of cutaneous and subcutaneous infections caused by rapidly growing mycobacteria. Eur J Clin Microbiol Infect Dis 32:161-188

13. Guiso N, Berbers G, Fry NK, He Q, Riffelmann M, Wirsing von König CH; EU Pertstrain group (2011) What to do and what not to do in serological diagnosis of pertussis: recommendations from EU reference laboratories. Eur J Clin Microbiol Infect Dis 30:307-312

14. Ahmad A, Khan A, Akhtar F, Yousuf S, Xess I, Khan LA, Manzoor N (2011) Fungicidal activity of thymol and carvacrol by disrupting ergosterol biosynthesis and membrane integrity against Candida. Eur J Clin Microbiol Infect Dis 30:41-50

15. van Hal SJ, Paterson DL, Gosbell IB (2011) Emergence of daptomycin resistance following vancomycin-unresponsive Staphylococcus aureus bacteraemia in a daptomycin-naïve patient - a review of the literature. Eur J Clin Microbiol Infect Dis 30:603-610

16. Montassier E, Batard E, Gastinne T, Potel G, de La Cochetière MF (2013) Recent changes in bacteremia in patients with cancer: a systematic review of epidemiology and antibiotic resistance. Eur J Clin Microbiol Infect Dis 32:841-850

17. Dancer SJ (2011) Hospital cleaning in the 21st century. Eur J Clin Microbiol Infect Dis 30:1473-1481

18. Dubourg G, Lagier JC, Armougom F, Robert C, Hamad I, Brouqui P, Raoult D (2013) The gut microbiota of a patient with resistant tuberculosis is more comprehensively studied by culturomics than by metagenomics. Eur J Clin Microbiol Infect Dis 32:637-645

19. Antinori S, Schifanella L, Corbellino M (2012) Leishmaniasis: new insights from an old and neglected disease. Eur J Clin Microbiol Infect Dis 31:109-118

20. Lambiase A, Catania MR, del Pezzo M, Rossano F, Terlizzi V, Sepe A, Raia V (2011) Achromobacter xylosoxidans respiratory tract infection in cystic fibrosis patients. Eur J Clin Microbiol Infect Dis 30:973-980

21. Wang Q-P, Wu Z-D, Wei J, Owen RL, Lun Z-R (2012) Human Angiostrongylus cantonensis: an update. Eur J Clin Microbiol Infect Dis 31:389-395 